\title{
Effect of early oral calcium supplementation on serum calcium and immunoreactive calcitonin concentration in preterm infants
}

\author{
L SANN, L DAVID, J A CHAYVIALLE, Y LASNE, AND M BETHENOD \\ Department of Neonatology and INSERM U 34, Hôpital Debrousse, Lyon, France
}

SUMMARY Oral calcium supplements $(80 \mathrm{mg} / \mathrm{kg}$ per $24 \mathrm{~h}$ ) were given to 23 preterm infants, and the course of serum calcium, magnesium, immunoreactive calcitonin, and gastrin was compared with a control group of 23 matched infants. In the supplemented group, serum calcium concentrations remained at the baseline level $(2 \cdot 31 \mathrm{mmol} / 1 \pm 0.18 \mathrm{SD})$ while a fall (from $2 \cdot 27 \pm 0.18$ to $1.91 \pm$ $0 \cdot 24 \mathrm{mmol} / \mathrm{l}$ ) was observed at $12-16$ hours of age in the control group, with 4 values $<1 \cdot 75 \mathrm{mmol} / 1$. There was no change in serum magnesium concentration in either group. The postnatal rise of serum immunoreactive calcitonin concentrations in the control group (from $171 \pm 135$ to $493 \pm 273 \mathrm{pg} / \mathrm{ml}$ at 12-48 hours of age) was not found in the supplemented group. There was a negative correlation between serum calcium and immunoreactive calcitonin levels in the control group, but not in the supplemented group. There was no correlation between serum immunoreactive calcitonin and gastrin concentrations. These data show that oral calcium supplementation can prevent early neonatal hypocalcaemia, and suggest that this effect is achieved at least in part through a reduction of the postnatal rise of serum immunoreactive calcitonin.

After birth there is a fall in serum calcium $(\mathrm{Ca})^{1-2}$ and a rise in serum immunoreactive calcitonin (iCT) levels. ${ }^{3-7}$ Preterm infants are particularly at risk from early hypocalcaemia. ${ }^{1-2} 8$ In order to compensate for the interruption of the large maternal supply, ${ }^{9}$ early supplements of oral calcium were given to preterm neonates. Its effect on serum $\mathrm{Ca}$, magnesium $(\mathrm{Mg})$, iCT, and immunoreactive gastrin (iGT) concentrations was compared with a control group. Our aim was to find out whether hypocalcaemia can be prevented in preterm neonates, and if it can, how early.

\section{Patients and methods}

Subjects. The study was carried out between February and September 1977 on 46 preterm infants. The study was approved by the ethical committee of the hospital.

Gestational age was assessed by the score of Dubowitz et al..$^{10}$ Birthweight was between the 25th and 75th centiles. ${ }^{11}$ Any infant with an Apgar score $<7$ at one minute was excluded. On admission to the unit (between 2 and 8 hours of age) each infant was placed randomly in one of two groups: a group of 23 infants supplemented with calcium ( $80 \mathrm{mg} / \mathrm{kg}$ per 24 hours for 5 days) or a group of 23 control infants. The calcium was given as $10 \%$ calcium gluconate in water (osmolality: 297 mosmol $/ \mathrm{kg} \mathrm{H}_{2} \mathrm{O}$ ), divided into between 6 and 8 doses a day and added to milk feeds.

Feeds were started at age 6-9 hours, either with breast milk collected from a milk bank (13 infants in the supplemented group and 10 infants in the control group) or by a 'humanised' formula. Mean calcium concentration was $24.5 \mathrm{mg} / 100 \mathrm{ml}$ for breast milk and $57 \mathrm{mg} / 100 \mathrm{ml}$ for the formula; mean $\mathrm{Ca} / \mathrm{P}$ ratio was 1.9 for breast milk and 1.6 for the formula.

Measurements. For serum $\mathrm{Ca}$ and $\mathrm{Mg}$ determinations blood was collected at regular intervals by heel prick before feeds: $2-8,12-16,18-24,44-52,62-76$, and 92-100 hours of age. Serum $\mathrm{Ca}$ and $\mathrm{Mg}$ were measured by atomic absorption (IL 343).

For serum iCT and iGT determinations, again blood samples were collected in microtubes by heel prick at admission (that is, 2-8 hours of age) and then at ages 12-16, or 18-24 hours. Blood collections were performed sequentially in 11 infants of the supplemented group and 13 of the control group. After centrifugation at $4^{\circ} \mathrm{C}$ sera were stored at $-28^{\circ} \mathrm{C}$. Samples were analysed in the same order to 
avoid interassay variation. Serum iCT was measured by the method of Tashjian, ${ }^{12}$ and David et al., ${ }^{6}$ the lower limit for the assay being $150 \mathrm{pg} / \mathrm{ml}$, with serum iCT undetectable in normal children and adults. For practical reasons, levels of serum iCT $<150 \mathrm{pg} / \mathrm{ml}$ were given a value of 75 when calculating the mean. Serum iGT was measured according to the technique of Ganguli and Hunter, ${ }^{13}$ and Sann et al.,${ }^{14}$ with a sensitivity of $15 \mathrm{pg} / \mathrm{ml}$.

Basal levels of serum $\mathrm{Ca}$ were analysed by Student's $t$ test and the levels of serum iCT by $\chi^{2}$ test. The postnatal course of serum $\mathrm{Ca}$ and iGT and iCT were analysed by paired $t$ tests.

\section{Results}

Clinical data. The main clinical data are shown in Table 1. There was no difference in gestational age, birthweight, or the volume of milk intake between the two groups.

Tolerance of calcium supplementation. The daily number (mean $\pm 1 \mathrm{SD}$ ) of regurgitations was $1.6 \pm 0.48$ in the control group and $2.0 \pm 0.44$ in the supplemented group. The daily number of stools was $4.39 \pm 0.26$ in the control group and 5.65 \pm 0.25 in the supplemented group. The maximum loss of weight since birth was $153 \pm 20 \mathrm{~g}$ in the control group and $147 \pm 21 \mathrm{~g}$ in the supplemented group. None of these differences between the two groups was significant. The later development of all infants was normal.

Postnatal course of serum $\mathrm{Ca}$ and Mg. This is shown on Fig. 1. The baseline $\mathrm{Ca}$ levels were similar in both groups. In the control group there was a decrease from (mean $\pm 1 \mathrm{SD}$ ) $2 \cdot 27 \pm 0 \cdot 18$ to $1.91 \pm 0.24$ $\mathrm{mmol} / 1$ at age $12-16$ hours $(\mathrm{P}<0.001)$. However, there was only a minor and nonsignificant decrease in the supplemented group, from $2.31 \pm 0.18$ to $2 \cdot 29 \pm 0 \cdot 14 \mathrm{mmol} / \mathrm{l}$. Serum $\mathrm{Ca}$ remained significantly lower in the control group than in the supplemented group until 92-100 hours of life. The

\section{Table 1 Clinical data}

\begin{tabular}{lll}
\hline & \multicolumn{1}{c}{ Calcium supplemented } & Control \\
\cline { 2 - 3 } & $(n=23)$ & $(n=23)$ \\
\hline $\begin{array}{c}\text { Gestational age } \\
\text { (weeks) }\end{array}$ & $\begin{array}{c}35 \cdot 0 \pm 0 \cdot 35^{*} \\
(32-37)\end{array}$ & $\begin{array}{c}34 \cdot 6 \pm 0 \cdot 44 \\
(32-37)\end{array}$ \\
$\begin{array}{c}\text { Birthweight (g) } \\
\text { Daily milk intake } \\
\text { (ml/kg) } \\
\text { Days 1 to 5 }\end{array}$ & $\begin{array}{c}1992 \pm 72 \\
(1400-2450)\end{array}$ & $\begin{array}{c}1965 \pm 70 \\
(1510-2650)\end{array}$ \\
$\begin{array}{c}\text { Daily calcium intake } \\
\text { (mg/kg) }\end{array}$ & $46 \pm 2 \cdot 5 \rightarrow 109 \pm 251 \pm 5 \rightarrow 112 \pm 3$ \\
Days 1 to 5 & $86 \pm 3 \rightarrow 122 \pm 5$ & $19 \pm 3 \rightarrow 45 \pm 4$ \\
\hline
\end{tabular}

*Mean \pm SD, ranges in parentheses.

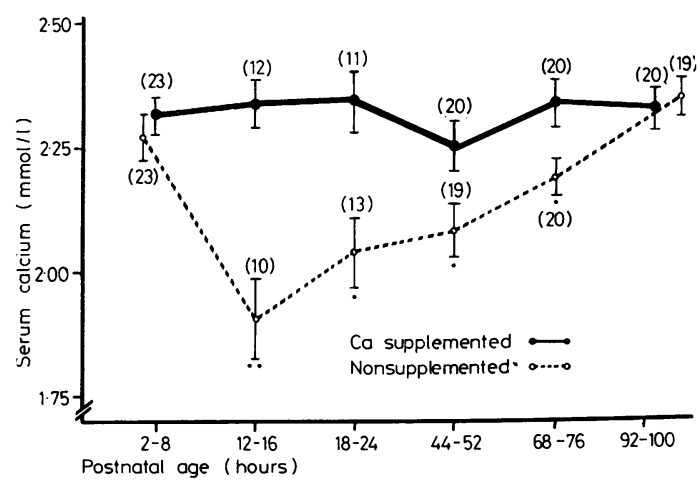

Asterisks indicate the significance of difference from baseline levels (paired $t$ test, ${ }^{*} P<0.05,{ }^{* *} P<0.01$ ). Number of subjects is given in parentheses.

Conversion: SI to traditional units-serum calcium: $1 \mathrm{mmol} / 1 \approx 4 \mathrm{mg}$ / $100 \mathrm{ml}$.

Fig. 1 Postnatal course of serum calcium concentration (mean $\pm S E M)$.

incidence of hypocalcaemia (that is serum $\mathrm{Ca}$ $<1.75 \mathrm{mmol} / \mathrm{l}$ ) was 4 of 23 in the control group and none of 23 in the supplemented group. In the supplemented group 2 infants exhibited hypercalcaemia on one occasion, 2.92 and $2.82 \mathrm{mmol} / 1$. All other values were $<2.75 \mathrm{mmol} / 1.24$ hours after stopping calcium supplementation, serum $\mathrm{Ca}$ levels $(2.39 \pm 0.16 \mathrm{mmol} / \mathrm{l})$ were not significantly different from those of the previous day, $2 \cdot 32 \pm 0 \cdot 18$ $\mathrm{mmol} / \mathrm{l}$.

Serum Mg was similar in both groups for the baseline levels, $0 \cdot 84 \pm 0.07 \mathrm{mmol} / 1$. No significant difference was observed at 12-24 hours $(0.82 \pm 0.01$ in the supplemented group v. $0.81 \pm 0.07 \mathrm{mmol} / \mathrm{l}$ in the control group) or later.

Postnatal course of serum iCT and iGT concentrations. The baseline levels for iCT (Fig. 2) (mean \pm 1 SD) were similar in the control group $(161 \pm 125 \mathrm{pg} / \mathrm{ml})$ and the supplemented group $(186 \pm 155 \mathrm{pg} / \mathrm{ml})$ $\left(\chi^{2} 0.621\right.$, NS). At 12 to 16 hours there was only one undetectable value in the control group, the detectable values being $553 \pm 232 \mathrm{pg} / \mathrm{ml}$; in the supplemented group there was also one undetectable value, the detectable values being $254 \pm 67 \mathrm{pg} / \mathrm{ml}$. The difference between the two groups was highly significant $\mathbf{P}<0.001$. At age 18 to 24 hours, there was still only one undetectable value in each group: the detectable values were $505 \pm 282 \mathrm{pg} / \mathrm{ml}$ in the control group and $372 \pm 145 \mathrm{pg} / \mathrm{ml}$ in the supplemented group. Despite the higher level of the mean concentration in the control group, the difference was not significant. The course of individual serum iCT concentrations is shown in Fig. 3. In the control group, serum iCT levels increased from $171 \pm 135$ to 
$\mathrm{Ca}$

supplement Control

$\mathrm{Ca}$ supplement Control

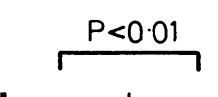

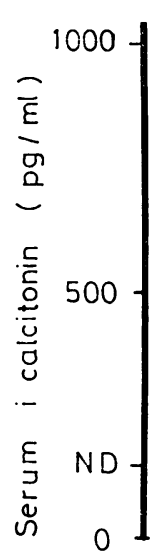
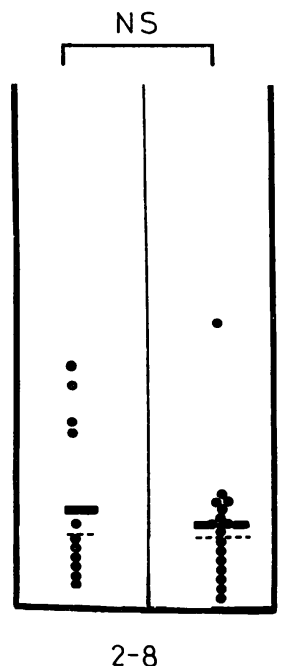

Postnatal age (hours)

$\mathrm{Ca}$ supplemented
infants

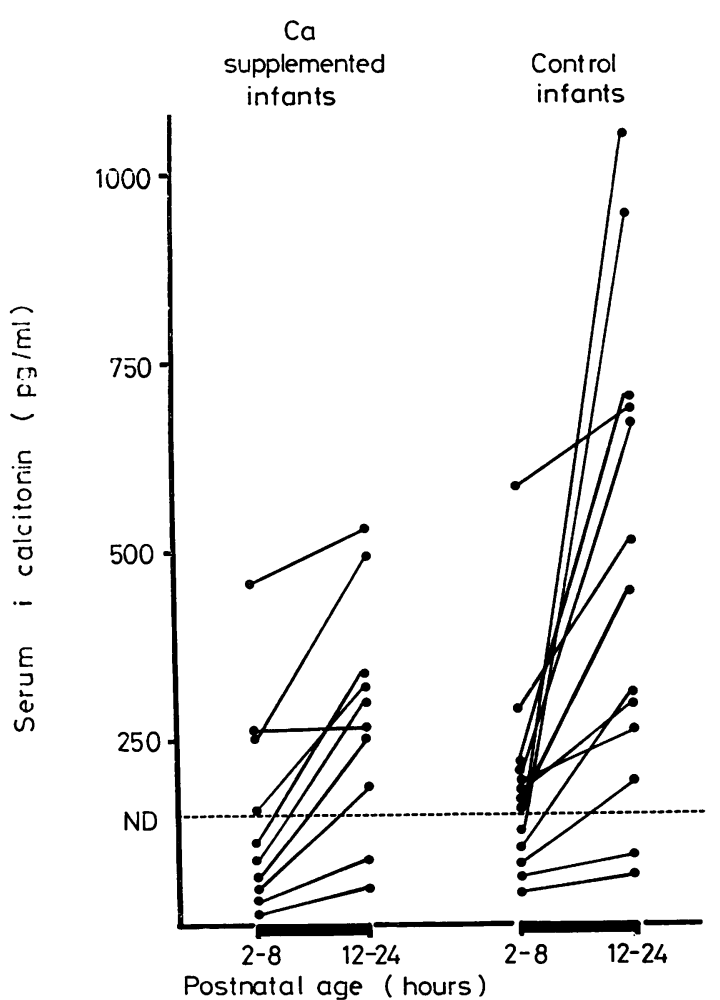

ND indicates the limit of detectability of the method.

Fig. 3 Course of serum immunoreactive calcitonin

concentration.
$\mathrm{Ca}$

supplement Control

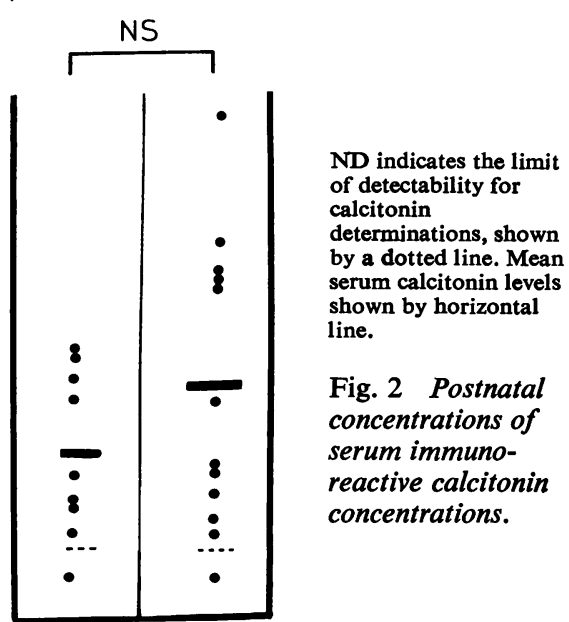

$18-24$
$493 \pm 273 \mathrm{pg} / \mathrm{ml}$ at 12 to 24 hours of age (paired $t$ test, $\mathrm{P}<0.01$ ); in the supplemented group, there was a slight but nonsignificant increase from $188 \pm 144$ to $303 \pm 164 \mathrm{pg} / \mathrm{ml}$. Between 12 and 24 hours, there was no significant difference in iCT levels when the infants were fed breast milk or formula.

The course of serum iGT is shown on Table 2. Baseline levels were similar in the control group and the supplemented group. In the control group there was an increase at 12-16 and at 18-24 hours $(\mathrm{P}<0.05)$. In the supplemented group however, the values at $12-16$ and at 18-24 hours were not significantly different from the baseline levels or from the values in the control group.

Correlation analysis. At the nadir of serum $\mathrm{Ca}$ concentrations in the control group, there was a highly significant negative correlation between serum $\mathrm{Ca}$ and $\mathrm{iCT}$ concentrations $(\mathrm{r}=-0.849$; $\mathrm{P}<0.001)$. In the supplemented group, no correlation was observed between serum $\mathrm{Ca}$ and iCT concentration at any time. There was no correlation between serum iCT and iGT levels or between serum $\mathrm{Ca}$ and $\mathrm{iGT}$ concentrations in either group.

Table 2 Course of mean ( $\pm 1 S D$ ) serum immunoreactive gastrin levels $(\mathrm{pg} / \mathrm{ml})$

\begin{tabular}{lll}
\hline Postnatal age (hours) & Supplemented group & Control group \\
\hline $2-8$ & $60 \pm 28$ & $63 \pm 20$ \\
$12-16$ & $93 \pm 55$ & $124 \pm 74^{*}$ \\
$18-24$ & $84 \pm 31$ & $132 \pm 87^{*}$ \\
\hline
\end{tabular}

*Significant $(P<0.05)$ difference from the baseline level. 


\section{Discussion}

During the transition from fetal to neonatal life, the preterm infant is removed from an environment where he received a net transplacental influx of $\mathbf{1 3 0}$ to $150 \mathrm{mg} / \mathrm{kg}$ per 24 hours of calcium. ${ }^{9}$ This removal results in a rapid fall in serum $\mathrm{Ca}$ which sometimes leads to hypocalcaemic convulsions. ${ }^{1-2} 8$ These data show that when these infants are supplemented with a large amount of calcium, the early fall in serum $\mathrm{Ca}$ can be prevented. This confirms the preliminary report of Brown et al. ${ }^{15}$ Recently, Moya and Doménech $^{16}$ also described the prevention of early neonatal hypocalcaemia with a formula supplemented with calcium. They suggested that the preterm neonate, like the fetus, is dependent on a large supply of calcium in order to maintain a normal serum $\mathrm{Ca}$. Our data also suggest that such large supplies of calcium can be achieved by the oral route; this is in agreement with the results of Sutton et al..$^{17}$ who showed that calcium given as a food supplement is almost completely absorbed by preterm infants.

Oral calcium supplements were well tolerated. Although there was a tendency for these infants to have a greater frequency of bowel movements than the control group, the difference was not significant. This is in contrast with the results of Brown et al. ${ }^{15}$ and attributable to the use of pure calcium gluconate instead of gluconate in syrup. Willis et al. ${ }^{18}$ recorded an increased incidence of necrotising enterocolitis in preterm infants with oral calcium supplements, but not if the calcium was given mixed with food. The only serious side effect in our study was the occurrence of transient hypercalcaemia in 2 of the supplemented infants, which disappeared when the supplements were stopped. Thus we favour oral calcium supplementation to prevent early hypocalcaemia in preterm neonates, provided that calcium is mixed with the foods and that serum $\mathrm{Ca}$ levels are regularly monitored.

Our results from the control group confirm previous work showing that hypercalcitonaemia participates in the occurrence of early hypocalcaemia. By contrast, the postnatal rise in serum iCT was limited in the supplemented group, and there was no correlation between serum $\mathrm{Ca}$ and $\mathrm{iCT}$ concentrations. It is unlikely that phosphorous or parathyroid hormone is involved since Brown et al..$^{15}$ found no effect of oral calcium on serum levels; nor was there any change in plasma 25-hydroxycholecalciferol levels. The fall in serum iCT levels may therefore be attributed to calcium gluconate administration.

The effect of calcium gluconate was surprising, since in adults intravenous or oral administration of calcium gluconate stimulates the secretion of calcitonin. ${ }^{19-20}$ In baby rats, Cooper et al. ${ }^{21}$ observed a rise in serum iCT in response to postprandial hypercalcaemia. However, in human preterm neonates Salle et al..$^{22}$ could detect no change in the postnatal rise of serum iCT during continuous infusion of calcium gluconate, despite an increase in serum $\mathrm{Ca}$. Our data thus suggest that the effect of oral calcium gluconate on serum iCT concentrations may be attributed to a digestive factor. According to some reports, gastrin is a potent calcitonin secretagogue in man, ${ }^{23-24}$ although this has not been confirmed by others. ${ }^{325-26}$ In the present study, the postnatal course of serum iCT and iGT was the same in both groups, but no correlation was observed. Our findings agree with the results of Cooper et al. ${ }^{21}$ in newborn rats. We conclude that the effect or oral calcium gluconate on serum iCT may be attributed to other digestive factors.

We thank Dr Jennie Mather for reviewing the manuscript.

\section{References}

1 Tsang R C, Oh W. Neonatal hypocalcemia in low birthweight infants. Pediatrics $1970 ; 45: 773-81$.

2 Rösli A, Fanconi A. Neonatal hypocalcaemia : early type in low birthweight newborns. Helv Paediatr Acta 1973; 28: 443-57.

3 Hesch R D, Woodhead S, Huefner M, Wolff H. Gastrointestinal stimulation of calcitonin in adults and newborns. Horm Metab Res 1973; 5: 235.

4 Bergman L, Kjellmer I, Selstam U. Calcitonin and parathyroid hormone relation to early neonatal hypocalcaemia in infants of diabetic mothers. Biol Neonate 1974; 24: 151-60.

5 Dirksen H C, Anast C S. Interrelationship of serum immunoreactive calcitonin (iCT) and serum calcium in newborn infants (abstract). Pediatr Res 1976; 10: 408.

- David L, Salle B, Chopard P, Grafmeyer D. Studies on circulating immunoreactive calcitonin in low birthweight infants during the first 48 hours of life. Helv Paediatr Acta 1977 ; 32: 39-48.

7 Hillman L S, Rojanasathit S, Slatopolsky E, Haddad J C. Serial measurements of serum calcium, magnesium, parathyroid hormone, calcitonin, and 25-hydroxyvitamin $D$ in premature and term infants during the first week of life. Pediatr Res 1977; 11 : 739-44.

8 Cockburn F, Brown J K, Belton N R, Forfar J O. Neonatal convulsions associated with primary disturbances of calcium, phosphorous, and magnesium metabolism. Arch Dis Child 1973; 48: 99-108.

- Shaw J C L. Parenteral nutrition in the management of sick low birthweight infants. Pediatr Clin North Am 1973; 20: 333-58.

10 Dubowitz L M S, Dubowitz V, Goldberg C J. Clinical assessment of gestational age in the newborn infant. $J$ Pediatr 1970; 77: 1-10.

11 Lubchenco L O, Hansman C, Dressler M, Boyd E. Intrauterine growth as estimated from liveborn birthweight data at 24 to 42 weeks of gestation. Pediatrics 1963; 32: 793-800.

12 Tashjian A H, Jr. Immunoassay of thyrocalcitonin. I. The method and its serological specificity. Endocrinology $1969 ; 84$ : 140-8. 
13 Ganguli P C, Hunter N M. Radio-immunoassay of gastrin in human plasma. $J$ Physiol (Lond) 1972; 220: 499-510.

14 Sann L, Chayvialle J A P, Bremond A, Lambert R. Serum gastrin level in early childhood. Arch Dis Child 1975; 50: $782-5$.

15 Brown D R, Tsang R C, Chen I W. Oral calcium supplementation in premature and asphyxiated neonates: preliminary report. J Pediatr 1976; 89: 973-7.

16 Moya $M$, Doménech $E$. Calcium intake in the first five days of life in the low birthweight infant. Effects of calcium supplements. Arch Dis Child 1978; 53: 784-7.

17 Sutton A, Mole R H, Barltrop D. Urinary and faecal excretion of marker calcium $\left({ }^{46} \mathrm{Ca}\right)$ by low birthweight infants. Arch Dis Child 1977; 52: 50-5.

18 Willis D M, Chabot J, Radde I C, Chance G W. Unsuspected hyperosmolality of oral solutions contributing to necrotizing enterocolitis in very low birthweight infants. Pediatrics 1977; 60: 535-8.

19 Tashjian A H, Jr. Howland B G, Melvin K E W, Hill L S, Jr. Immunoassay of human calcitonin: clinical measurement, relation to serum calcium, and studies in patients with medullary carcinoma. $N$ Engl J Med 1970; 283: 890-5.

20 Heynen G, Franchimont P. Human calcitonin radioimmunoassay in normal and pathological conditions. Eur J Clin Invest 1974; 4: 213-22.

21 Cooper G W, Obie J F, Toverud S W, Munson P L. Elevated serum calcitonin and serum calcium during suckling in the baby rat. Endocrinology $1977 ; 101$ : 1657-64.
22 Salle B, David L, Chopard P, Grafmeyer D C, Renaud H. Prevention of early neonatal hypocalcemia in low birth weight infants with continuous calcium infusion. Effect on serum calcium, phosphorus, magnesium, and circulating immunoreactive parathyroid hormone and calcitonin. Pediatr Res $1977 ; 11$ : 1180-5.

23 Cooper G W, Schwesinger W H, Mahgoub A M, Ontjes D A. Thyrocalcitonin: stimulation of secretion by pentagastrin. Science $1971 ; 172$ : 1238-40.

24 Sizemore G W, Go V L W, Kaplan E L, Sanzenbacher L J, Holtermüller K H, Arnaud C D. Relation of calcitonin and gastrin in the Zollinger-Ellison syndrome and medullary carcinoma of the thyroid. $N$ Engl J Med 1973; 288: $641-4$.

25 Owang C, Heath J, Sizemore G W, Go V L W. Gastrin stimulation of human calcitonin secretion (abstract). Gastroenterology 1976; 70: 925.

${ }_{26}$ Fahrenkrug J, Schaffalitzky de Muckadell O B, Relifed J F. Serum calcitonin in hypergastrinaemia due to achlorhydria. Acta Endocrinol (Kbh) 1977; 86: 140-5.

Correspondence to Dr L Sann, Department of Neonatology and INSERM U 34, Hôpital Debrousse, 29 rue Sœur Bouvier, 69322 Lyon, Cedex 1, France.

Received 10 May 1979 